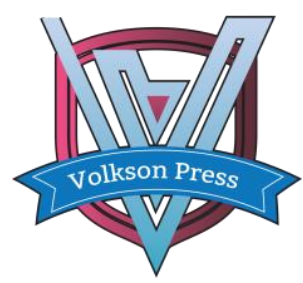

Contents List available at VOLKSON PRESS

Economics \& Management Innovations(EMI)

DOI : http://doi.org/10.26480/icemi.01.2017.142.143

\title{
Using the Analytic Hierarchy Process to Investigate the Functions of Green Building Materials
}

\author{
Hsien-Chang Shen ${ }^{1}$, Wen-Tsan Lin², An-Jin Shie ${ }^{3 *}$ \\ ${ }^{1}$ Art Design at China-ASEAN International College, Dhurakij Pundit University, Thailand \\ ${ }^{2}$ Department of Industrial Engineering and Management, National Chin-Yi University of Technology \\ ${ }^{3}$ MBA, China-ASEAN International College, Dhurakij Pundit University, Thailand \\ *s948904@mail.yzu.edu.tw
}

This is an open access article distributed under the Creative Commons Attribution License, which permits unrestricted use, distribution, and reproduction in any medium, provided the original work is properly cited.

\section{ARTICLE DETAILS}

\section{Article History:}

Received 02 october 2017 Accepted 06 october 2017 Available online 11 october 2017

\section{Keywords:}

Green Building Materials, Fuzzy Theory, Aggregate

Decision, In-Depth Interview

\section{ABSTRACT}

The present study examines customer acceptance of the use of green building materials to replace traditional building materials in the context of the global trend towards sustainable development. To ensure the performance of green building materials, the study constructed a certification system for green building materials by developing suitable measures for the "safety," "use of natural resources," "energy efficiency," and "usability" of green building materials. For "safety," the research proposed the concepts of "natural building materials" and "chemical building materials." For "use of natural resources," the concepts of "abundant resources" and "green processes" were proposed. For "energy efficiency," the concepts of "resource recycling" and "resource reduction" were proposed. For "usability," the concept of "high-performance building materials" was proposed. These dimensions were used to collect data in order to develop the most appropriate usage based on business cultures in the green building materials industry. Finally, we discuss the implications of our findings.

\section{Introduction}

Buildings offer a safe place to live, and the use of green building materials can also ensure a healthy living space. In 1992, the International Materials Research Council defined green building materials as materials that minimize the impact on the environment. These materials' process of obtainment, product manufacturing, usage, and recycling following usage also must not harm human health. Based on health and environmental needs and regulatory trends (Doczy \& Abdelrazig, 2017), green building materials are a contemporary trend that cannot be ignored. This research is a case study of the functions of green building materials and explores the practical experiences of the use of green building materials in public construction in order to examine the functionality of green building materials and whether their market usage has become universal. This study investigates the inclusion of building materials in the development of the product cycle, so that architects, interior designers, related industries, and the general public can carry out one-stop shopping, thereby meeting the demands of consumers at each level.

\section{Research Method}

In order to meet the aforementioned research objectives, the present study explored items for the selection of green building materials by using hierarchical analysis on convergent items for pair comparison, determining priority dimensions, and identifying the best selection criteria. We used the analytic hierarchy process (AHP) to identify key factors for the representation and standardization of problems. The present study used an overall objective combined with the "safety," "use of natural resources," "usability," and "energy efficiency" dimensions to design the questionnaire. We combined and supplemented insufficient factors at the "quantitative" stage, achieving complementary "quality and quantity," and increasing overall effectiveness.

\subsection{Step 1 for the AHP}

Based on a literature review and identification of the main areas of focus in the green building materials industry (Akadiri et al., 2013; Doczy \& Abdelrazig, 2017), we aggregated factors of the same type and ranked items that the experts believed are important in the order of their proportion. The present study constructed the AHP hierarchical structure, which includes the dimensions of "safety," "use of natural resources," "usability," and "energy efficiency." The first level is the primary objective, which is evident in the title of the present study: to examine the functions of green building materials. The second level is the measurement dimensions, which are "safety," "use of natural resources," "usability," and "energy efficiency." The third level includes the key factors: four related items for each of the four dimensions. The relationships between each of the levels are shown in Figure 1.

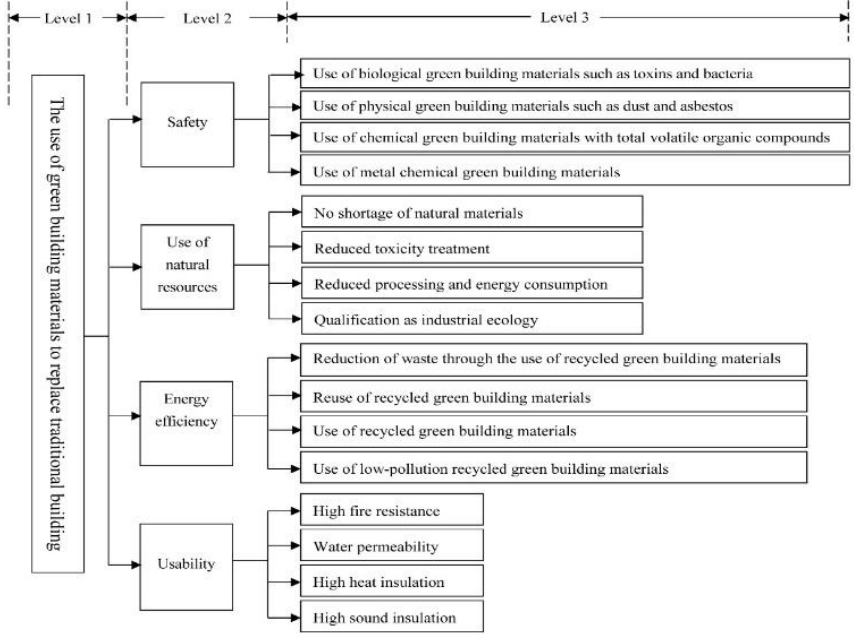

Figure 1. The AHP Hierarchical Framework for Green Building Materials

\subsection{Step 2 for Fuzzy Established}

The present study established triangular fuzzy numbers, and then used them to aggregate the views of respondents, showing the fuzziness of the views of respondents on the importance of paired factors. We used Dompere (2013) approximation approach, which takes consistency into consideration and is a normalized concept. Next, the present study used the center of gravity method for defuzzification. The advantage of the center of gravity method is that it is practical and objective, and does not 
require the input of the preferences of the decision maker.

\subsection{Step 3 for In-Depth Interviews}

In order to gain an in-depth understanding of expectations for the performance indicators of green building materials personnel and obtain information that the researcher did not predict or that has not been discovered by other research methods, we conducted interviews with house builders, contractors, and firms in the construction industry. The quantitative results from the AHP analysis were used to create the outline and questions to be used in the interviews. The interviews focused on four dimensions: "safety," "use of natural resources," "usability," and "energy efficiency."

\section{Empirical Analysis}

This section consists of two parts. The first part is the hierarchical analysis, which explores the professional knowledge of green building materials personnel, including their ability, attitude, and quality, as well as the feelings of the users of green building materials after use. The second part is the indepth interviews used to verify the important items identified by the statistical analysis to test whether the functions of green building materials meet the expectations of the customers and the industry. The subjects of the research are house builders, contractors, and firms in the construction industry. This approach is more suitable for a very small sample that is difficult to obtain (Akadiri et al., 2013; Doczy \& Abdelrazig, 2017).

\subsection{Fuzzy Hierarchical Analysis}

The present study established a hierarchical framework with four criteria dimensions and 16 sub-dimensions, using AHP and fuzzy analysis. Table 1 Total Performance Value

\begin{tabular}{|c|c|c|c|c|c|c|}
\hline $\begin{array}{l}\text { Dimension } \\
\text { Weighting }\end{array}$ & Item & No. & $\begin{array}{l}\text { Weight } \\
\text { Value }\end{array}$ & $\begin{array}{l}\text { t Overall Rankin } \\
\text { Weight g }\end{array}$ & $\begin{array}{l}\text { Fuzzy } \\
\text { Weightin } \\
\text { g }\end{array}$ & $\begin{array}{l}\text { Rankin } \\
\mathrm{g}\end{array}$ \\
\hline \multirow{4}{*}{$\begin{array}{l}\text { Safety } \\
0.245\end{array}$} & 1. & $\begin{array}{l}\text { Use of biological green building } \\
\text { materials such as toxins and } \\
\text { bacteria. }\end{array}$ & d 0.486 & 0.12521 & 0.311 & 2 \\
\hline & 2. & $\begin{array}{l}\text { Use of physical green building } \\
\text { materials such as dust and } \\
\text { asbestos. }\end{array}$ & d 0.230 & 0.05927 & 0.166 & 15 \\
\hline & 3. & $\begin{array}{l}\text { Use of chemical green building } \\
\text { materials with total volatile } \\
\text { organic compounds. }\end{array}$ & g 0.175 & 0.045111 & 0.180 & 14 \\
\hline & 4. & $\begin{array}{l}\text { Use of metal chemical green } \\
\text { building materials. }\end{array}$ & n 0.109 & 0.028115 & 0.125 & 16 \\
\hline \multirow{4}{*}{$\begin{array}{l}\text { Use } \\
\text { natural } \\
\text { resources } \\
0.233\end{array}$} & 5. & $\begin{array}{l}\text { No shortage of natural } \\
\text { materials. }\end{array}$ & 0.265 & 0.06835 & 0.210 & 11 \\
\hline & of 6. & Reduced toxicity treatment. & 0.088 & 0.022716 & 0.275 & 5 \\
\hline & 7 & $\begin{array}{l}\text { Reduced processing and energy } \\
\text { consumption. }\end{array}$ & $\mathrm{y}_{0.176}$ & 0.045310 & 0.275 & 5 \\
\hline & 8. & $\begin{array}{l}\text { Qualification as industrial } \\
\text { ecology. }\end{array}$ & 0.353 & $\begin{array}{rr}0.091 \quad 4 \\
\end{array}$ & 0.241 & 8 \\
\hline \multirow{4}{*}{$\begin{array}{l}\text { Energy } \\
\text { efficiency } \\
0.121\end{array}$} & 9. & $\begin{array}{l}\text { Reduction of waste through the } \\
\text { use of recycled green building } \\
\text { materials. }\end{array}$ & $\begin{array}{l}\text { e } \\
\text { g0.457 }\end{array}$ & 0.11772 & 0.194 & 12 \\
\hline & & $\begin{array}{l}\text { Reuse of recycled green } \\
\text { building materials. }\end{array}$ & $\mathrm{n}_{0.235}$ & 0.0616 & 0.214 & 10 \\
\hline & 11. & $\begin{array}{l}\text { Use of recycled green building } \\
\text { materials. }\end{array}$ & $\mathrm{g}_{0.162}$ & $0.042 \quad 13$ & 0.273 & 7 \\
\hline & 12. & $\begin{array}{l}\text { Use of low-pollution recycled } \\
\text { green building materials. }\end{array}$ & $d_{0.146}$ & $0.038 \quad 14$ & 0.319 & 1 \\
\hline \multirow{4}{*}{$\begin{array}{l}\text { Usability } \\
0.096\end{array}$} & 13. & High fire resistance. & 0.420 & $\begin{array}{l}0.108 \quad 3 \\
0.1103\end{array}$ & 0.183 & 13 \\
\hline & 14. & Water permeability. & 0.163 & $0.042 \quad 12$ & 0.281 & 4 \\
\hline & 15. & High heat insulation. & 0.222 & $0.572 \quad 8$ & 0.225 & 9 \\
\hline & 16. & High sound insulation. & 0.195 & $0.050 \quad 9$ & 0.311 & 2 \\
\hline
\end{tabular}

The results (see Table 1) showed that of the four dimensions, "safety" accounts for a ratio of $24.5 \%$, mainly because safety can ensure the personal safety of the customers, no matter how beautiful the house. Without safety, the beauty of the house is meaningless. The "use of natural resources" dimension also takes up a high proportion at $23.3 \%$. One of the reasons that explain why green building materials can replace traditional building materials is that aside from the fact that they have the same utility as traditional building materials, they also have a lower impact on the environment. The "energy efficiency" dimension accounts for a ratio of
$12.1 \%$. For any customer, the ability to reduce stages or energy consumption in the manufacturing process can reduce costs, while product quality can be maintained at the same time as costs are reduced. The "usability" dimension accounts for a ratio of $9.6 \%$. Customers hope that they can also protect their property when using green building materials. Therefore, usability is an important dimension.

\subsection{In-Depth Interviews}

The theme of the present study is "the effectiveness and flexibility of green building materials as a replacement for traditional building materials." We used hierarchical analysis according to the coding at each level to identify the similarities and differences among all of the concepts. For similarities, we proposed tangibility, reliability, responsiveness, assurance, and care. These indicators related to green building materials personnel have appropriate focus points for extraction as reference items. In terms of differences, assessing areas of difference enables us to propose strategies and recommendations for the improvement and strengthening of green building materials.

\section{Conclusions}

After using the AHP, we obtained the weight orders for each of the items to determine which of the items needed to be strengthened and improved, used all of the problems faced as focus points for the interviews, and categorized the items that should be used as important referent items for designing the content of the questionnaire for the in-depth interviews, with the results summarized as follows:

* For "safety," the concepts of "natural building materials" and "chemical building materials" were proposed. "Natural building materials" can be formed from the basic items, "use of biological green building materials such as toxins and bacteria" and "use of physical green building materials such as dust and asbestos." The "chemical building materials" item can be divided into "use of chemical green building materials with total volatile organic compounds" and "use of metal chemical green building materials."

* For "use of natural resources," the concepts of "abundant resources" and "green processes" were proposed. The "abundant resources" concept can be formed from the basic item, "no shortage of natural materials." The "green processes" item can be divided into the basic items, "reduced toxicity treatment," "reduced processing and energy consumption," and "qualification as industrial ecology."

* For "energy efficiency," the concepts of "resource recycling" and "resource reduction" were proposed. The "resource recycling" concept can be formed by the basic concepts, "reuse of recycled green building materials" and "use of recycled green building materials." The "resource reduction" item can be formed from the basic items, "reduction of waste through the use of recycled green building materials" and "use of lowpollution recycled green building materials."

* For "usability," the concept of "high performance building materials" was proposed. The concept of "high performance building materials" can be formed from the basic items, "high fire resistance," "water permeability," "high heat insulation," and "high sound insulation."

\section{References}

[1] Akadiri, P. O., Olomolaiye, P. O., \& Chinyio, E. A. 2013. Multi-criteria evaluation model for the selection of sustainable materials for building projects. Automation in Construction, 30: 113-125.

[2] Doczy, R. \& Abdelrazig, Y. 2017. Green buildings case study analysis using AHP and MAUT in sustainability and costs. Journal of Architectural Engineering, 23(3).

[3] Dompere, K. K. 2013. Fuzziness and foundations of exact and inexact sciences. Studies in Fuzziness and Soft Computing, 290: 1-195. 